\title{
Effect of treatment Osteosarcoma (Mg-63) cells with Vitamin C, Green tea and their combination (An-in vitro study)
}

\author{
Hiam R. Hussien*, Amr H.M. El Bolok, Sherif F. Elgayar and Maii I. A.Sholqamy \\ Oral Pathology Department, Faculty of Dentistry, Minia University. \\ *Corresponding author: hiamrifaat985@gmail.com; Tel: +01099056509 .
}

\section{Article information}

Received: 6 November 2021

Revised: 24 November 2021

Accepted: 24 November 2021

\section{Key words}

Osteosarcoma (OS)

Vitamin C

Green tea

Combination

Autophagy.

\begin{abstract}
Background: Osteosarcoma (OS) is the most common primary bone malignancy that affects children and adolescents. It is considered as a serious threat to the human health globally. For many years plants and natural constitutes components such as vitamin $\mathrm{C}$ (ascorbic acid), green tea have been used as anti-cancer drugs.

Aim: The objective of this in vitro study was to investigate the effect of vitamin $\mathrm{C}$, green tea and their combination on $\mathrm{Mg}-63$ cell line.

Material Methods: Treatment of cell line (Mg-63) by different concentrations of vitamin, green tea and their combination was done to evaluate the viability of the treated cells by SRB assay. Microscopic examination and were applied. Results: Regarding cytotoxicity effect of vitamin C, green tea and their combination on $\mathrm{Mg}$-63cell line, it was noticed that cell distribution showed a variable arrest at different phase of cell division. Where there was nonsignificant difference of arrested cells of these drugs compared with its value in non-treated G0-G1 phase control cells while there was a significant elevated arrest of treated cells during the G2-M phase and the significant difference of cell arrest at G2-M phase was type of treatment related.

Conclusion: From the results of the present study, we noticed that vitamin green tea and their combination have cytotoxic effect on $\mathrm{Mg}-63$ cell line, it also induced an effect on the cell cycle distribution, resulting in apoptosis, necrosis and autophagy.
\end{abstract}

\section{Introduction}

We deal with cancer as it is one of the major causes of death all over the world [1]. Osteosarcoma is the most common primary pediatric bone malignancy, derived from primitive bone-forming (osteoid producing) mesenchymal cells [2]. Until now the real cause of bone cancer is unknown, this may due to different genetic types with lack of molecular alterations [3], [4]. For several years ago, natural plants and their extracts have been used for various treatment purposes such as cancer [5]. In ancient years, various studies were confirmed that different concentrations of vitamin $\mathrm{C}$ inhibited the tumor growth and caused cancer death [6]. Different compounds are considered to be anticancer, polyphenols as gallacatechins, flavonoids and tannis are type of these compounds [7]. Green tea are added to a person's nutrition for health improvement, Gallacatechins are present in green Tea, it is thought including polyphenols in a person's diet can improve health and reduce risk of cancers by being natural antioxidants [8].

\footnotetext{
Aim

The aim of the current study is to investigate the effect of vitamin $\mathrm{C}$, green tea and their combination on $\mathrm{Mg}-63$ cell line.
}

Mg-63 osteosarcoma cell line was obtained from Cell Culture Department (NAWA SIENTIFIC) in the form of frozenvial.invitro cultivation of human tumor tissues (Osteosarcoma).

\section{(B)Drugs:-}

Mg-63 Cells treated with vitamin C, green tea extracts and their combination with $\mathrm{IC}_{50}$ concentration.

\section{Cytotoxicity Assay principal}

SRB assay: -

It is SRB Sulforhodamine B colorimetric assay for cytotoxicity screening, used One of the most widely used methods for in vitro cytotoxicity screening. The assay relies on the ability of SRB to bind to protein components of cells that have been fixed to tissue-culture plates by trichloroacetic acid (TCA). SRB is a bright-pink amino-xanthene dye with two sulfonic groups that bind to basic amino-acid residues under mild acidic conditions, and dissociate under basic conditions. Cells were maintained in DMEM media supplemented with $100 \mathrm{mg} / \mathrm{mL}$ of streptomycin, 100units/mL of penicillinand $10 \%$ ofheat-inactivated fetal bovine serum in humidified, $5 \%$ (v/v) CO2atmosphere at $37^{\circ}$ [9],[10].

\section{Materials and Methods}

(A)Cell line:- 


\section{Microscopic examination}

\section{Hematoxylin and eosin staining of MG-63 cell line :-}

Hematoxylin and Eosin stain was performed according to Alshehri etal., (2019) where IC50 treated and untreated cells were harvested by cold centrifugation (Jouan-Ki-22,France) residual adherent cells were trypsenized and processed in the same way . [11] Deposited cells were re-suspended in $0.5 \mathrm{ml}$ of phosphate buffer saline (PBS) Fifty microliters of treated and untreated cells were dispensed and spread in circular way on clean slides (3 for each treatment). Slides were air-dried, methanol fixed and rehydrated in descending concentrations of alcohol $(100 \%, 90 \%, 75 \%$ and $50 \%)$. Slides were washed in distilled water for $5 \mathrm{~min}$ [11].

The slides were immersed in filtered hematoxylin (HE) stain for $3 \mathrm{~min}$ and washed with distilled water twice. Slides were immersed in filtered eosin stain for 5 seconds and washed with distilled water. Dried slides were immersed in xylene, mounted with Canada balsam then coverslips were placed and left to dry.

Five microscopic fields of each slide were photomicrographed using the power of $400 \times$. This was done using a digital camera (Canon, Japan), which was mounted on a light microscope. Images were transferred to the computer system for analysis. Field selection was based on the presence of the highest number of apoptotic cells. The photomicrographs were qualitatively evaluated for the presence of morphological criteria of apoptosis.

\section{(3)Autophagy assay.}

Autophagic cell death is assessed using acridine orange lysosomal stain coupled with flowcytometric analysis. After treatment with test compounds for 24/480r72 cells (105 cells) are collected by trypsinization and washed twice with ice-cold PBS (pH 7.4). Cells are stained with acridine orange $(10 \mu \mathrm{M})$ and incubated in dark at $37^{\circ} \mathrm{C}$ for 30 minutes. After staining, cells are injected via ACEA Novocyte ${ }^{\mathrm{TM}}$ flowcytometer (and acridine orange fluorescent signals is analyzed using FL1 signal detector ( $\lambda$ ex/em 488/530 nm). For each sample, 12,000 events are acquired and net fluorescent intensities (NFI) are quantified using ACEA NovoExpress ${ }^{\mathrm{TM}}$ [12].

\section{Results:-}

\section{Cytotoxicity results:-}

SRB Assay was employed. Data obtained revealed cytotoxic effect of Mg-63 cells with vitamin C, green tea and combination. Tab.(1)

\section{Microscopic examination: -}

Effects of different concentrations of vitamin, green tea and their combination by microscopic evaluations. Figs. (1),(2),(3),(4),(5) .

\section{Autophagy results:-}

Autophagic cell death assessment in $\mathrm{Mg}-63$ cells treated vitamin $\mathrm{C}$, green tea and their combination with (IC50 $\mu \mathrm{M})$ using the acridine orange lysosomal stain coupled with the flow cytometric analysis. The green curve for the negative control (untreated), and the red one for the treated cells. Vitamin C caused autophagic cell death followed by combination then least effect was green tea. Fig.(6) Tab. (2)

\section{(1)Fig1}

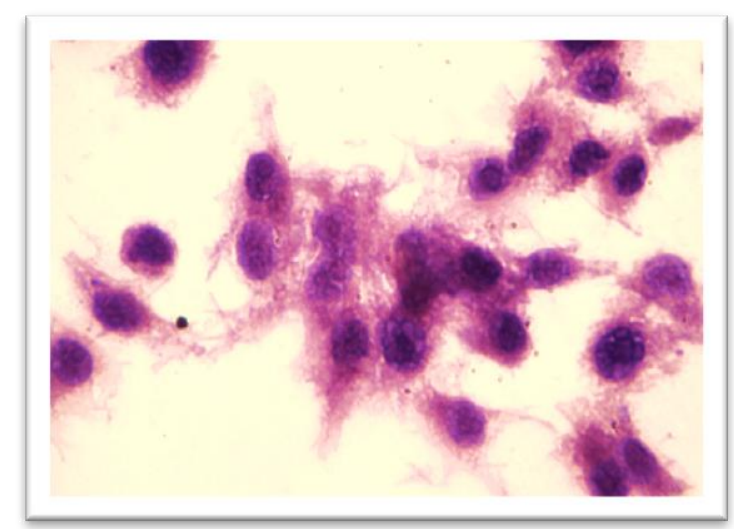

Figure 1: A photomicrograph showing malignant cells showing hyperchromatism and cellular and nuclear pleomoephism (H and E, Original magnification 100X oil).

(2)Fig2

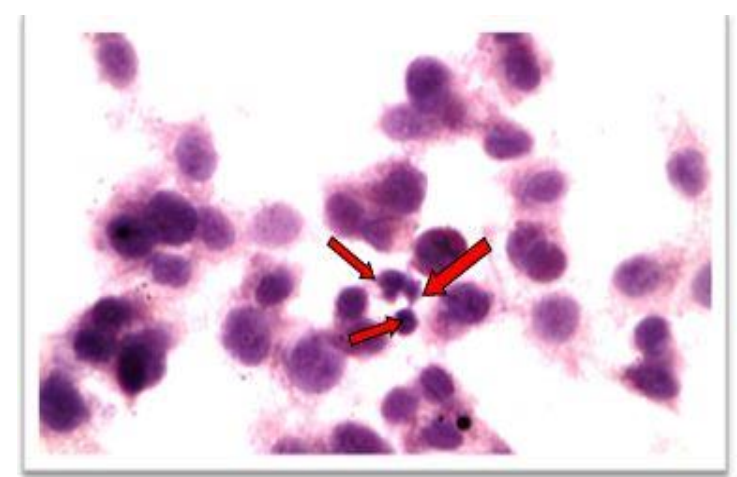

Figure 2: A photomicrograph showing sheets of malignant cells. Shrunken apoptotic cells with irregular cellular and nuclear membranes (Yellow arrows) (H and E, Original magnification 100X Oil).

\section{(3)Vitamin C}

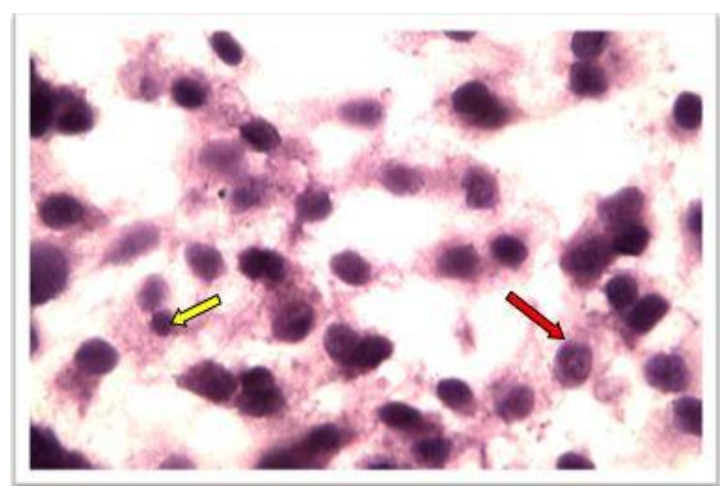

Figure 3 : A photomicrograph showing malignant cells. Few apoptotic cells could be detected showing cellular shrinkage (Yellow arrow) and peripheral condensation of chromatin (Red arrow) (H and E, Original magnification 100X Oil). 


\section{(4)Green tea}

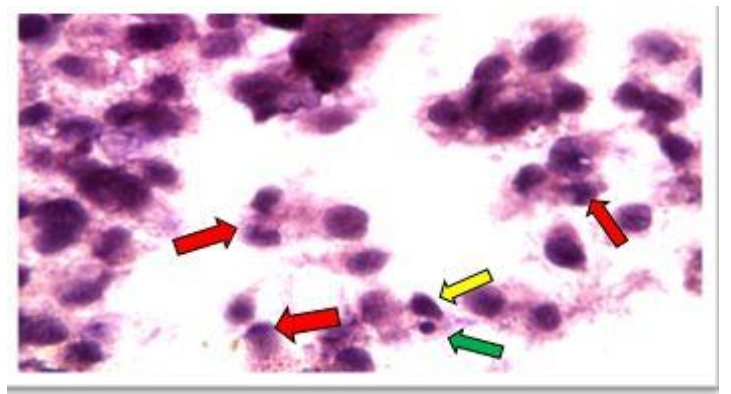

Figure 4 : A photomicrograph showing sheets of malignant cells. Shrunken apoptotic cells (Yellow arrows) with peripheral condensation of chromatin (Red arrows) could also be detected. An apoptotic body could also be seen (Green arrow) (H and E, Original magnification 100X Oil).

\section{(5)Combination:-}

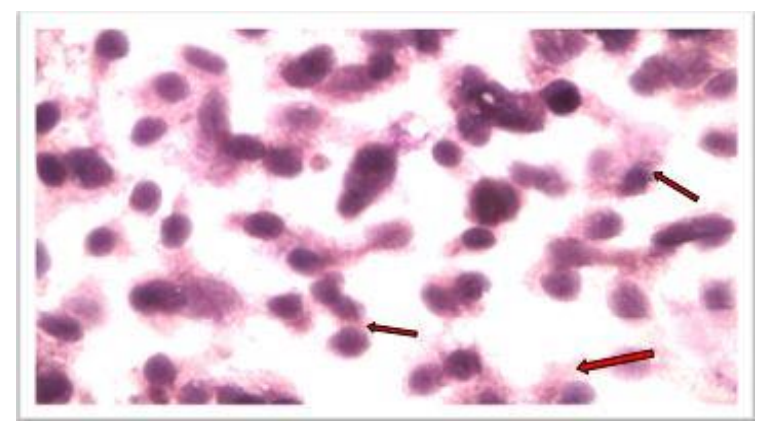

Figure 5: A photomicrograph showing sheets of malignant epithelial cells. Few apoptotic cells could be detected with irregular cellular and nuclear membranes (red arrows) ( $\mathrm{H}$ and $\mathrm{E}$, Original magnification 100X Oil).

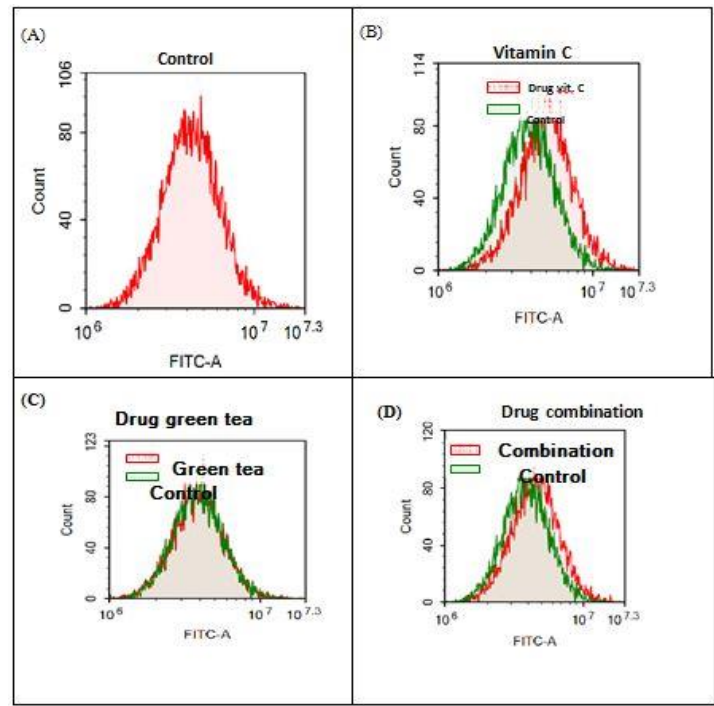

Figure 6: Effect of $\mathrm{Mg}-63$ cells treated cells treated with vitamin C, green tea and combination on autophagy. Control (A), vitamin C (B), green tea $(\mathrm{C})$, Combination(D).

\section{Table (1) 1. Cytotoxicity results:-}

SRB Assay was employed. Data obtained revealed cytotoxic effect of $\mathrm{Mg}-63$ cells with vitamin $\mathrm{C}$, green tea and combination.

\begin{tabular}{|l|l|r|r|r|}
\hline \multicolumn{2}{|c|}{ compound } & \multicolumn{1}{c|}{ Vitamin C } & \multicolumn{1}{c|}{ Green tea } & \multicolumn{1}{c|}{ Combination } \\
\hline \multirow{3}{*}{ Conc. } & $10 \mathrm{ug} / \mathrm{ml}$ & 97.9376 & 98.3501 & 99.6268 \\
\cline { 2 - 5 } & SD & 0.4339 & 0.76122 & 0.34694 \\
\cline { 2 - 5 } & $100 \mathrm{ug} / \mathrm{ml}$ & 93.3415 & 68.711 & 69.1824 \\
\cline { 2 - 5 } & SD & 0.9686 & 0.7349 & 0.58 \\
\hline
\end{tabular}

\section{Autophagy results:-}

Autophagic cell death assessment in Mg-63 cells treated vitamin C, green tea and their combination with (IC50 $\mu \mathrm{M}$ ) using the acridine orange lysosomal stain coupled with the flow cytometric analysis. The green curve for the negative control (untreated), and the red one for the treated cells. Vitamin C caused autophagic cell death followed by combination then least effect was green tea.

Table (2)

\begin{tabular}{|l|l|l|c|c|}
\hline Sample & Mean $\mathbf{x}$ & Median x & $\begin{array}{l}\text { Mean control } \\
\text { reated sample }\end{array}$ & $\begin{array}{l}\text { Median control } \\
\text { related sample }\end{array}$ \\
\hline 1-Control & $4,565,223$ & $4,205,568$ & - & - \\
\hline 2- Vitamin C & $5.410,875$ & $5,050,733$ & $4,201,886$ & $3,878,195$ \\
\hline 3-Green tea & $4,211,453$ & $3,902,621$ & $4,201,886$ & $3,878,195$ \\
\hline 4-Comination & $4.884,969$ & $4,537,918$ & $4,201,886$ & $3,878,195$ \\
\hline
\end{tabular}

\section{Discussion: -}

The aim of the present study is to investigate the cytotoxic effect of vitamin C green tea and their combination on Mg-63 osteosarcoma cell line. We confirmed that all three drugs have cytotoxic effect but with different degree, resulting in cell cycle arrest in with inhibition of mitosis followed by inducing different types of cell death such as apoptosis, necrosis and autophagy but with varying degree.

Our data explained clearly the effect of in -vitro cytotoxic effects of vitamin $\mathrm{C}$ green tea and their combination on $\mathrm{Mg}-63$ osteosarcoma cell line after 72 hours. photomicrography and cytological evaluation were done to confirm and clarify SRB results. Careful examination revealed that, the major criteria of apoptosis and necrosis were showed among different concentrations of the three drugs.

Microscopic examinations were done, in morphological analysis, untreated control cells showed a relatively some morphological changes in the form of nuclear and cellular pleomorphism due to the malignant nature of the cells. Only few control cells showed early morphological characteristics of apoptosis such as cellular and nuclear chromatin condensation and apoptotic bodies. Fig.(1),(2)

Cells treated with vitamin $\mathrm{C}$ of showed sheets of malignant cells. Few apoptotic cells could also be detected. A photomicrograph showing malignant cells. Few apoptotic cells could be detected showing cellular shrinkage and peripheral condensation of chromatin. Figs.(3) 
Cells treated with green Tea reflected sheets of malignant cells. Apoptotic shrunken cells could be detected. The cells show peripheral condensation of chromatin and irregular cell and nuclear membranes. A photomicrograph showing sheets of malignant cells. Shrunken apoptotic cells with peripheral condensation of chromatin and apoptotic bodies were detected. Fig.(4)

Cells treated with combination explained sheets of malignant cells. Few apoptotic cells could be detected in this group. A photomicrograph showing sheets of malignant cells. Few apoptotic cells could be detected with irregular cellular and nuclear membranes. Fig.(5)

These indicated that these drugs induced in vitro cell death by three different mechanisms of autophagy apoptosis and necrosis. All of these results are in agreement with the following :- $\quad\left(O^{\prime} L e a r y ~ B R\right.$ et al.,2020, Ma E.,et al.,2014 and Venturelli S.,) [13],[14],[15] confirmed that vitamin C possess anti-cancer effect and they explained their confirmations by examining the effect of vitamin $\mathrm{C}$ on various cancer cell lines of different type of tumor.

(Belin et al., 2009; Chen et al., 2005, 2008; Valenti et al., 2014), [16],[17],[18], studied the antitumor effect vitamin C on another osteosarcoma cell line (G292) as the following:that vitamin $\mathrm{C}$ caused inhibition of cell growth of different osteosarcoma cell line such as $\mathbf{G 2 9 2}$ this inhibition is dose dependent of vitamin $\mathrm{C}$ resulting in decrease growth of tumor cells in low concentrations of vitamin $\mathrm{C}$ and apoptosis of tumor cells in high concentrations., this also confirmed by Wang $\mathbf{J}$. et al., 2018, Ni J et al., 2018 and Luo $k w$. et al.,2017),[19],[20],[21] .

( Wang J. et al., 2018, Ni J et al., 2018 and Luo kw. et al.,2017), [19],[20],[21] assured that GTPs caused inhibition of growth of tumor cells resulting in apoptosis in different tumor types.

Furthermore, (Liu L et al.,2015 and Tsao A S.),[22],[23] demonstrated that in these GTPs affect cell cycle regulation and caspase-3 that has essential role in apoptosis. Observing the results of our study, we concluded that autophagy cell death was induced with treatment of Mg-63 cells with vitamin $\mathrm{C}$ using acridine orange in relation to control group. Fig.(6B) also we noticed that $\mathrm{Mg}-63$ cells treated with green tea produce autophagy but with lower percentage than that of vitamin $\mathrm{C}$. Fig.(6C) when we used Mg-63cell cells treated with combination, autophagy cell death was observed but not more than Mg-63 cells treated with vitamin $\mathrm{C}$ and greater than green tea. Fig.(6D).

These results are in agreement with (Valenti MT, et al.2014) [18] reported that vitamin C used in treatment of osteosarcoma were able to produce apoptosis and autophagic cell death in vitro.

Wang, $X$ et 2019 [19] assured that polyphenols by being the main component of GTPs contain special properties as they cause autophagic cell death in cancer death.

\section{Conclusions}

From the results of the current study we found that vitamin C, green tea and their combination have cytotoxic effect on $\mathrm{Mg}-63$ cell line but with different levels, also induced apoptosis, necrosis and Autophagy.

\section{List of Abbreviations}

OS: Osteosarcoma.

GT: green tea.

IC50: Half-maximal inhibitory concentration.

SRB: Sulforhodamine B assay.

TCA: trichloroacetic acid.

DMEM: Modified Eagle Medium.

PI: Propidium iodide.

DNA: Deoxyribonucleic acid.

RNA: Ribonucleic acid.

DEMSO: Dimethyl Sulfoxide.

PBS: Phosphate Buffer Saline.

NFI: Net fluorescent intensities.

HE: Hematoxylin eosin.

GTPs: Green tea polyphenols.

\section{Acknowledgements}

Thanks with all gratitude and appreciation for:-

Prof. Amr Helmy Moustafa El Bolok

Professor and Head of oral and maxillofacial, pathology Department, Faculty of Dentistry, Minia University. amrelbolok@yahoo.com

Prof. Sherif Farouk Elgayar

Assistant professor of oral and maxillofacial Pathology Department.

Faculty of Dentistry, Minia University.

selgayar@gmail.com

Dr. Maii Ibrahim Ali Sholqamy

Lecturer of oral and maxillofacial Pathology Department.

Faculty of Dentistry, Minia University.

Maii.sholkamy@yahoo.com

Thank you for your consideration of this manuscript

Sincerely,

Dr. Hiam Rifaat Hussein.

\section{REFERENCES}

(1) Ghosh, D.; Venkataramani, P.; Nandi, S.; Bhattacharjee, S. CRISPR-Cas9 a boon or bane: The bumpy road ahead to cacer therapeutics. Cancer Cell Int.

2019, 19, 12 . 
(2)Lindsey BA, Markel JE, Kleinerman ES. (2017) "Osteosarcoma Overview. Rheumatol Ther". Jun;4(1):25-43.

(3)L. Mirabello, B. Zhu, R. Koster, E. Karlins, M. Dean, M. Yeager, M . Gianferante, L.G. Spector, L.M. Morton, D. Karyadi, L.L. Robison, G .T. Armstrong, $\mathrm{S}$.

Frequency of pathogenic germline variants in cancer-susceptibility genes in patients with osteosarcoma

JAMA Oncol. (2020)

(4)K. Scotlandi, C.M. Hattinger, E. Pellegrini, M. Gambarotti, M. Serra Genomics and therapeutic vulnerabilities of primary bone tumors

Cells, 9 (2020)

(5)Sivaraj R, Rahman PKSM, Rajiv P, Vanathi P, et al. Venckatesh R.(2014)" Biosynthesis and characterization of Acalypha indica mediated copper oxide nanoparticles and evaluation of its antimicrobial and anticancer activity". Spectrochimica Acta Part A: Molecular and Biomolecular Spectroscopy. ;129:255-258.

(6) Carr, A.C and Cook, J.et al.(2018) Intravenous Vitamin C for Cancer Therapy-Identifying the Current Gaps in Our Knowledge. Front. Physiol. 9, 1182.

(7) Azmi AS, Bhat SH, Hanif S , Hadi SM et al.(2006). "Plant polyphenols mobilize endogenous copper in human peripheral lymphocytes leading to oxidative DNA breakage: A putative mechanism for anticancer Properties". FEBS Letters. ;580:533-538.

(8) Apostolou A, Stagos D, Galitsiou E, Spyrou A, Haroutounian S, Portesis N, Trizoglou I, Hayes AW, Tsatsakis AM, Kouretas D et al. (2013) "Assessment of polyphenolic content, antioxidant activity, protection against ROS-induced DNA damage and anticancer activity of Viti vinifera stem extracts". Food and Chemical Toxicology. ;61:6068.

(9) Kasinski AL, Kelnar K, Stahlhut C, Orellana E, Zhao J, Shimer E, Dysart S, Chen X, Bader AG, Slack FJ.et al.(2015) A combinatorial microRNA therapeutics approach to suppressing non-small cell lung cancer. Oncogene. 2015;34(27):3547-3555

(10) Grada A, Otero-Vinas M, Prieto-Castrillo F, Obagi Z, Falanga V.et al (February 2017). "Research Techniques Made Simple: Analysis of Collective Cell Migration Using the Wound Healing Assay". The Journal of Investigative Dermatology. 137 (2): e11:e16.

(11)Mohammed A. Alshehri , Piotr M. Wierzbicki , Hassan F. Kaboo, Mohamed S.M. Nasr, Mohamed E. Amer, Tamer M.M. Abuamara, Doaa A. Badr, Kamel A. Saleh, Ahmed E. Fazary, Aly F. Mohamed (2019): In vitro evaluation of electroporated gold nanoparticles and extremely-low frequency electromagnetic field anticancer activity against Hep-2 laryngeal cancer cells. FOLIA HISTOCHEMICA ET CYTOBIOLOGICA Vol. 57, No. 4, 2019 pp. 159-167.

(12)Bashmail HA, Alamoudi AA, Noorwali A, Hegazy GA, AJabnoor G, Choudhry H, Al-Abd AM. Thymoquinone synergizes gemcitabine anti-breast cancer activity via modulating its apoptotic and autophagic activities. Sci Rep. 2018;8(1):11674

(13) O’Leary B.R., Alexander M.S., Du J., Moose D.L., Henry M.D., Cullen J.J. Pharmacological ascorbate inhibits pancreatic cancer metastases via a peroxide-mediated mechanism. Sci. Rep. 2020;10:17649.
(14) Ma E., Chen P., Wilkins H.M., Wang T., Swerdlow R.H., Chen Q. Pharmacologic ascorbate induces neuroblastoma cell death by hydrogen peroxide mediated DNA damage and reduction in cancer cell glycolysis. Free Radic.Biol.Med. 2017;113:36-47.

(15)Venturelli S., Sinnberg T.W., Berger A., Noor S., Levesque M.P., Böcker A., Niessner H., Lauer U.M., Bitzer M., Garbe C., et al. Epigenetic Impacts of Ascorbate on Human Metastatic Melanoma Cells. Front. Oncol. 2014;4 doi: 10.3389/fonc.2014.00227.

(16)Belin, S., Kaya, F., Duisit, G., Giacometti, S., $\square$

Chen, Q., Espey, M. G., Krishna, M. C., Mitchell, J. B., Corpe, C. P., Buettner, G. R., ... Levine, M. (2005). Pharmacologic ascorbic acid concentrations selectively kill cancer cells: Action as a pro-drug to deliver hydrogen peroxide to tissues. Proceedings of the National Academy of Sciences of the United States ofAmerica, 102, 13604 13609.

(17)Chen, Q., Espey, M. $\quad$ G., Sun, A. $\quad$ Y., Pooput, C., Kirk, K. L., Krishna, M. C., ... Levine, M. (2008). Pharmacologic doses of ascorbate act as a prooxidant and decrease growth of aggressive tumor xenografts in mice. Proceedings of the National Academy of Sciences, 105, 11105-11109.

(18)Chen, Q., Espey, M. G., Krishna, M. C., Mitchell, J. B., Corpe, C. P., Buettner, G. R., ... Levine, M. (2005). Pharmacologic ascorbic acid concentrations selectively kill cancer cells: Action as a pro-drug to deliver hydrogen peroxide to tissues. Proceedings of the National Academy of Sciences of the United States of America, 102, 13604 13609.

(19)Valenti, M.T., Zanatta, M., Donatelli, L., Viviano, G., Cavallini, C. , Scupoli, M. T., \& Dalle Carbonare, L. U. C. A. (2014). Ascorbic acid induces either differentiation or apoptosis in MG-63 osteosarcoma lineage. Anticancer Research, 34, 1617-1627.

(20)Wang J., Pan Y., Hu J., Ma Q., Xu Y., Zhang Y., Zhang F., Liu Y. Tea polyphenols induce $\mathrm{S}$ phase arrest and apoptosis in gallbladder cancer cells. Braz. J. Med. Biol. Res. 2018;51:6891.

(20) Ni J., Guo X., Wang H., Zhou T., Wang X. Differences in the Effects of EGCG on Chromosomal Stability and Cell Growth between Normal and Colon Cancer Cells. Molecules. 2018;23:788.

(21)Luo K.W., Wei C., Lung W.Y., Wei X.Y., Cheng B.H., Cai Z.M., Huang W.R. EGCG inhibited bladder cancer SW780 cell proliferation and migration both in vitro and in vivo via down-regulation of NF- $\mathrm{NB}$ and MMP-9. J. Nutr. Biochem. 2017;41:56-64.

(22)Liu L., Hou L., Gu S., Zuo X., Meng D., Luo M., Zhang X., Huang S., Zhao X. Molecular mechanism of epigallocatechin-3-gallate in human esophageal squamous cell carcinoma in vitro and in vivo. Oncol. Rep. 2015;33:297-303.

(23) Wang, X.; Lan, Z.; He, J.; Lai, Q.; Yao, X.; Li, Q.; Liu, Y.; Lai, H.; Gu, C.; Yan, Q.; et al. LncRNA SNHG6 promotes chemoresistance through ULK1-induced autophagy by sponging miR-26a-5p in colorectal cancer cells. Cancer Cell Int. 2019, 19, 234. 